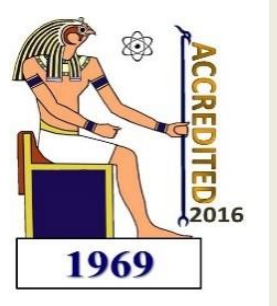

Delta Journal of Science

Available online at https://djs.journals.ekb.eg/

Research Article

MICROBIOLOGY

\title{
Isolation, identification and screening of cellulolytic activity of some fungi from different sources and localities in Egypt
}

\author{
Mostafa M. El-Sheekh ${ }^{a^{*}}$, Mohammed Y. Bedaiwy ${ }^{a}$, Aya A. El-ngar ${ }^{\mathrm{a}}$, Eman W. Elgammal $^{\mathrm{b}}$ \\ ${ }^{a}$ Botany Department, Faculty of Science, Tanta University, Tanta, Egypt, P.O. 31527 \\ ${ }^{\mathrm{b}}$ Chemistry of Natural and Microbial Products Department, National Research Center, 33-El Bohouth st., \\ Dokki, Giza, Egypt, P.O.12622 \\ *Corresponding author email: mostafaelsheikh@science.tanta.edu.eg
}

\section{KEY WORDS}

Cellulolytic

fungi,

Cellulolytic

activity, Congo

red, Clear zone,

Screening

\section{ABSTRACT}

Cellulases are a series of hydrolytic enzymes that can hydrolyze cellulosic biomass into a simpler sugar. In the present study, thirty-one fungal species were isolated from different places in Al-Gharbia and Aswan governorates. These fungal species were identified and found to belong to twelve genera "Trichoderma, Cladosporium, Aspergillus, Botritrichom, Rhizopus, Cephalosporium, Fusarium, Penicillium, Mucor, Circinella, Alternaria and Rhodotorula". All identified fungal species were screened for cellulolytic activity based on clear zone diameter using $0.1 \%$ congo red. Out of thirty-one fungal species, 27 species showed cellulolytic activity and the highest activity was recorded by Trichoderma viride and isolate No. 1 of Aspergillus niger. All 27 fungal species were tested for three cellulolytic enzymes as "carboxymethyl cellulase (CMCase), $\beta$ - glucosidase ( $\beta$ Gase), and filterpaper cellulase (FPase)". The highest total cellulolytic activity for three cellulolytic enzymes was recorded by isolate No. 1 of Aspergillus niger (79.3 U/ml). Among all tested isolates of Aspergillus niger isolate No. 1 isolated from Tanta was the best one. 


\section{Introduction}

Cellulose is the basic structure of the plant cell wall (Pandey et al., 2020). It is unbranched, linear homopolymer of glucose subunits linked by $\beta \quad 1,4$ glycosidic linkages (Rathore et al., 2014). Also, it is one of the most important carbon sources all over the world so, the degradation of cellulosic substances is significant for the global carbon source (Pandey et al., 2020). Degradation of cellulosic substances may be achieved using chemicals, enzymes, or a combination of them (Reddy et al., 2014).

Cellulase is an extracellular enzyme secreted by a variety of microorganisms that causes cellulose hydrolysis by the synergistic action of the enzymes constituent. Three main types of cellulases were described by (Klysov, 1990). At the first, Endoglucanase (Endo 1,4 $\beta$ glucanases) breaks down the internal bond to destroy the cellulose crystalline structure to form individual polysaccharide chains, then cellobiohydrolase (Exo-cellulase) cleaves 2-4 units from the ends of the exposed chains produced by endocellulases, finally cellobiase $(\beta$ galactosidase) hydrolyzes the cellobiose into individual glucan. These cellulolytic enzymes work together to complete the hydrolysis of crystalline cellulose (Sari et al., 2016).

Cellulases are the most widely utilized commercial enzyme in a variety of industries, including biofuels, drinks, food, feed, textiles, paper, agriculture, and pharmaceuticals. These enzymes are employed alone or in combination with other enzymes in these industries (Ejaz et al., 2021). As a result, several studies are being conducted to find new microorganisms capable of producing cellulase with higher activity (Duarte $\boldsymbol{e t}$ al., 2017). Fungi, bacteria, and actinomycetes are microorganisms that produce cellulases. However, fungi are the primary producers of extracellular cellulase enzyme. High productivity, low cost, rapid production, and ease of recovery from the medium are just a few of the many benefits associated with an enzyme produced from fungus (Sari $\boldsymbol{e t}$ al., 2017).

This study aimed to isolate, identify and screen fungi that have higher cellulolytic activity.

\section{Material and methods}

\subsection{Samples collection}

Eight samples (six samples from Tanta, Al-Gharbia governorate, Egypt, and two samples from Isna, Aswan governorate, Egypt) were investigated. 
Samples from Al-Gharbia governorate are two different soil $(1,2)$, water sample, two agricultural wastes (wheat straw and linen straw), and compost sample from the Faculty of Agriculture, Tanta University. From Aswan Governorate, two soil samples were collected (3, 4). Agricultural wastes and Soil samples were air-dried and stored in sterilized bags at room temperature. Linen straw was soaked for 4 days, and Linen soaked water was stored in a sterilized bottle at $4^{\circ} \mathrm{C}$.

\subsection{Isolation of Fungi from different collected samples}

Fungi were isolated from the above-mentioned collected samples. The isolates were cultured on potato dextrose agar (PDA) medium containing antibacterial streptomycin (100 $\mathrm{mg} / \mathrm{l})$. The agricultural wastes were chopped into small pieces $(5 \mathrm{~mm})$ and spread on the surface of the plate containing a sterilized PDA media. One $\mathrm{ml}$ of liquid sample was distributed on a sterilized plate surface containing sterilized PDA medium. Serial dilutions for soil samples and compost were performed as Celestino et al., (2014) and CruzLachica et al., (2018) by mixing $1 \mathrm{gm}$ of the sample well with $100 \mathrm{ml}$ sterilized distilled water then, moving $1 \mathrm{ml}$ of this mixture to a tube containing $9 \mathrm{ml}$ sterilized distilled water and shaking thoroughly. After that, dilutions were subsequently made up to $10^{-5}$, then $1 \mathrm{ml}$ of each dilution was plated in a sterilized PDA media. The plates were incubated at $28 \pm 2{ }^{\circ} \mathrm{C}$ for 7 days. After incubation, growing fungal colonies were purified and maintained on PDA slants at $4^{\circ} \mathrm{C}$.

\subsection{Identification of isolated fungi}

The pure isolates were identified based on cultural, morphological features as color and growth of the colony, and spore coloration and microscopic features of hyphae and spore's structures according to consult keys given in standard books on mycology (Booth, 1971; Raper and Fennell, 1977; Moubasher and AbdelHafez, 1978; Domsch et al., 1980; Kitch and Pitt, 1992).

2.4. Screening for the cellulolytic activity of isolated fungi

\subsubsection{Screening for cellulolytic activity} using solid culture

Fungal isolates were tested for their cellulolytic activity based on the diameter of clear zones around growing fungal colonies using Czapek's agar medium containing carboxy methylcellulose (CMC) as a sole carbon source instead of sucrose (Hasanin et al., 2018). Modified Czapek's agar ingredients were $(\mathrm{g} / \mathrm{l})$ : Carboxymethyl cellulose, 10.0; $\mathrm{NaNO}_{3}, 2.0 ; \mathrm{K}_{2} \mathrm{HPO}_{4}$, $1.0 ; \mathrm{KCl}, 0.5 ; \mathrm{MgSO}_{4}, 0.5 ; \mathrm{FeSO}_{4}, 0.01$; Agar, 20.0. After preparing, the media 
were sterilized at $121^{\circ} \mathrm{C}$ for $15 \mathrm{~min}$ and poured into the sterilized Petri dishes. After solidification, separately discs of fungal isolates $(5 \mathrm{~mm})$ were inoculated and incubated at $30 \pm 2^{\circ} \mathrm{C}$ for 5 days. After incubation, $5 \mathrm{ml}$ of congo red $(0.1 \% \mathrm{w} / \mathrm{v})$ were added to each dish for $20 \mathrm{~min}$ then, the dishes were washed with $1 \mathrm{M} \mathrm{NaCl}$ for $20 \mathrm{~min}$. After that, dishes were treated with $5 \%$ acetic acid for $2 \mathrm{~min}$ then washed with distilled water (Darwesh et al., 2020). The clear zone is an indicator for cellulose degradation.

\subsubsection{Screening for the cellulolytic activity of the isolated fungi using liquid culture}

The positive isolates that gave a clear zone around fungal colony in the previous step were tested using Modified Mandel Weber medium: 10.0 carboxymethyl cellulose, 2.0 $\mathrm{KH}_{2} \mathrm{PO}_{4}, 1.4 \quad\left(\mathrm{NH}_{4}\right)_{2} \mathrm{SO}_{4}, \quad 0.3$ $\mathrm{MgSO}_{4} .7 \mathrm{H}_{2} \mathrm{O}, 0.3 \mathrm{CaCl}_{2}, 0.02$ tween-80, $0.005 \quad \mathrm{FeSO}_{4} .7 \mathrm{H}_{2} \mathrm{O}, \quad 0.0016$ $\mathrm{MnSO}_{4} \cdot 7 \mathrm{H}_{2} \mathrm{O}, 0.0014 \mathrm{ZnSO}_{4} \cdot \mathrm{H}_{2} \mathrm{O}, 0.002$ $\mathrm{CoCl}_{2}, \quad 0.75$ Peptone, 0.3 Urea, 0.25 yeast extract (Jasani et al., 2016). pH was adjusted at 4.8 . One disc $(5 \mathrm{~mm})$ of each fungal isolates was inoculated in a $100 \mathrm{ml}$ flask containing $25 \mathrm{ml}$ sterilized medium and incubated for 7 days at $30^{\circ} \mathrm{C}$. Three replicas were applied for each fungus. After incubation, filtration was carried out using Whatman No. 1 filter paper. All fungal filtrates were centrifuged at $10000 \mathrm{rpm}$ for $10 \mathrm{~min}$, and the supernatants were collected for measuring of activities of carboxymethyl cellulase (CMCase), $\beta$ - glucosidase ( $\beta$ Gase), and filter-paper cellulase (FPase) (Nathan et al., 2014).

\subsection{Assay of cellulolytic enzymes}

Activities of carboxymethyl cellulase (CMCase), $\beta$ - glucosidase ( $\beta$ Gase), and filter-paper cellulase (FPase), were measured as cellulolytic activity according to Mandels et al., (1976). One unit of filter-paper cellulase (FPase), carboxy-methyl cellulase (CMCase), and $\beta$ - glucosidase ( $\beta$ Gase) were defined as $\mu \mathrm{g}$ of reducing sugars released per min per gram of dry weight under standard assay conditions. A standard curve of pure glucose was formed using concentrations from $(0.03$ to $0.3 \mathrm{mg} / \mathrm{ml}$ ).

\subsubsection{Carboxymethyl cellulase (CMCase) assay}

Carboxy-methyl cellulase (CMCase) was measured according to Mandels et al., (1976) by adding $0.5 \mathrm{ml}$ of fungal filtrate and $1 \%$ of CMC dissolved in $0.05 \mathrm{M}$ of Na-citrate buffer $(\mathrm{pH}$ 4.8). The reaction mixture was incubated at $45^{\circ} \mathrm{C}$ for $45 \mathrm{~min}$ then, $1 \mathrm{ml}$ of DNS reagent was added to each tube and immersed in a boiling water bath for 
10 min, after cooling, and the amount of reducing sugar (glucose) was measured at $540 \mathrm{~nm}$. This assay was applied for each one of three replicas of fungal suspension.

\subsection{2. $\beta$ - glucosidase ( $\beta$ Gase) assay}

$\beta$ - glucosidase ( $\beta$ Gase) was measured according to Mandels et al., (1976) by adding $0.5 \mathrm{ml}$ of fungal filtrate and $1 \%$ of $\mathrm{D}$-salicin dissolved in $0.05 \mathrm{M}$ of Na-citrate buffer ( $\mathrm{pH}$ 4.8). The reaction mixture was incubated at $45^{\circ} \mathrm{C}$ for $45 \mathrm{~min}$ then, $1 \mathrm{ml}$ of DNS reagent was added to each tube and immersed in a boiling water bath for $10 \mathrm{~min}$, after cooling, and the amount of reducing sugar (glucose) was measured at $540 \mathrm{~nm}$. This assay was applied for each one of three replicas of fungal suspension.

\subsubsection{Filter-paper cellulase (FPase) assay}

Filter-paper cellulase (FPase) was measured according to Mandels et al., (1976) by adding $0.5 \mathrm{ml}$ of fungal filtrate and $50 \mathrm{mg}$ of filter paper (Whatman No. 1) dissolved in $1 \mathrm{ml}$ of $0.05 \mathrm{M}$ of $\mathrm{Na}$ citrate buffer $(\mathrm{pH}$ 4.8). The reaction mixture was incubated at $45^{\circ} \mathrm{C}$ for 45 min then, $1 \mathrm{ml}$ of DNS reagent was added to each tube and immersed in a boiling water bath for $10 \mathrm{~min}$, after cooling, and the amount of reducing sugar (glucose) was measured at $540 \mathrm{~nm}$. This assay was applied for each one of three replicas of fungal suspension. After cooling, and the amount of reducing sugar (glucose) was measured at $540 \mathrm{~nm}$. This assay was applied for each one of three replicas of fungal suspension.

\subsection{Statistical analysis}

Triplicate was performed for all measurements. Statistical analysis was done using analysis of variance (ANOVA) one-way test, the significance of the mean difference was detected according to (Duncan, 1955). Values are very highly significant when $\mathrm{P} \leq 0.001$, highly significant when $\mathrm{P} \leq 0.01$, significant when $\mathrm{P} \leq 0.05$, and insignificant when $\mathrm{P} \geq 0.05$. Results were reported as mean value $\pm \mathrm{SD}$. In the figure, SD was displayed as Y-error bars.

\section{Results}

\subsection{Isolation of Fungi from different} collected samples

Thirty-one fungal species were isolated from different samples and belonging to twelve genera "Trichoderma, Cladosporium, Aspergillus, Botritrichom, Rhizopus, Cephalosporium, Fusarium, Penicillium, Mucor, Circinella, Alternaria and yeast". The fungal isolates were purified and identified according to the morphological and microscopic features of their hyphae and spore's structures as indicated by consult keys in standard mycology books (Table 1). 
Table 1. List of fungal species isolated from different sources

\begin{tabular}{|c|c|}
\hline Fungal species & Source \\
\hline Trichoderma viride (persoon) Harz & \multirow{10}{*}{ Soil sample No. 1 from Tanta } \\
\hline Cladosporium cladosporiodes Link & \\
\hline Aspergillus sediwii (isolate 1) Thom and Church & \\
\hline Botritrichom spp. Saccardo and Marchal & \\
\hline Aspergillus niger (isolate 1) Van Tieghem & \\
\hline Rhizopus spp. (isolate 1) Ehrenberg & \\
\hline Cephalosporium rose-grisium Saksena & \\
\hline Fusarium oxysporium Schlechtendal & \\
\hline Aspergillus flavus (isolate 1) Link & \\
\hline Aspergillus candidus (isolate 1) Link & \\
\hline Rhizopus spp. (isolate 2) Ehrenberg & Wheat straw from Tanta \\
\hline Aspergillus flavus (isolate 2) Link & \multirow{3}{*}{ Compost from Tanta } \\
\hline Aspergillus fumigates Fresenius & \\
\hline Cephalosporium spp. Corda & \\
\hline Rhizopus spp. (isolate No. 3) Ehrenberg & \multirow[b]{2}{*}{ Soil sample No. 2 from Tanta } \\
\hline $\begin{array}{l}\text { Aspergillus sulphorus (Fresenius) Thom and } \\
\text { Church }\end{array}$ & \\
\hline Penicillium digitatum Saccard & \multirow{6}{*}{ Soil sample No. 3 from Aswan } \\
\hline Aspergillus sediwii (isolate 2)Thom and Church & \\
\hline Aspergillus niger (isolate 2) Van Tieghem & \\
\hline Aspergillus flavus (isolate 3) Link & \\
\hline Aspergillus candidus (isolate 2) Link & \\
\hline Aspergillus terrus Thom & \\
\hline Aspergillus niger (isolate 3) Van Tieghem & \multirow{4}{*}{ Soil sample No. 4 from Aswan } \\
\hline Aspergillus flavus (isolate 4) link & \\
\hline Aspergillus ochraceus K. Wilhelm & \\
\hline Penicillium notatum Westling & \\
\hline Mucor spp. (isolate 1) Micheli & Linen straw from Tanta \\
\hline Mucor spp. (isolate 2) Micheli & \multirow{4}{*}{ water sample from Tanta } \\
\hline Circinella simplex Van Tieghem (Plate XII G) & \\
\hline Alternaria alternate Nees & \\
\hline Rhodotorula spp. (Fresen) & \\
\hline
\end{tabular}


3.2. Screening for cellulolytic activity from isolated fungi

\subsubsection{Screening for cellulolytic activity} using solid culture

Among 31 fungi, 27 were found to have cellulolytic activity as indicated by the clear zones, which ranged from 1.5 to $9.0 \mathrm{~cm}$ diameter as shown in Table 2.
The highest clear zone $(9 \mathrm{~cm})$ was recorded by isolate 1 of Aspergillus niger and Trichoderma viride. Moreover, the lowest clear zone diameter $(1.5 \mathrm{~cm})$ was recorded by Cladosporium cladosporiodes.

Table 2. Screening for cellulolytic activity using solid culture

\begin{tabular}{|c|c|}
\hline Fungal species & Clear zone diameter $(\mathrm{cm})$ \\
\hline Trichoderma viride & $9.0 \pm 0.00$ \\
\hline Cladosporium cladosporiodes & $1.5 \pm 0.05$ \\
\hline Aspergillus sediwii (isolate No. 1) & $3.4 \pm 0.10$ \\
\hline Botritrichom spp. & $3.3 \pm 0.10$ \\
\hline Aspergillus niger (isolate No. 1) & $9.0 \pm 0.00$ \\
\hline Rhizopus spp. (isolate No. 1) & $0.0 \pm 0.00$ \\
\hline Cephalosporium rose-grisium & $2.3 \pm 0.10$ \\
\hline Fusarium oxysporium & $4.1 \pm 0.10$ \\
\hline Aspergillus flavus (isolate No. 1) & $5.0 \pm 0.00$ \\
\hline Aspergillus candidus (isolate No. 1) & $2.9 \pm 0.10$ \\
\hline Rhizopus spp. (isolate No. 2) & $0.0 \pm 0.00$ \\
\hline Aspergillus flavus (isolate No. 2) & $3.6 \pm 0.20$ \\
\hline Cephalosporium spp. & $5.6 \pm 0.11$ \\
\hline Rhizopus spp. (isolate No. 3) & $0.0 \pm 0.00$ \\
\hline Aspergillus sulphorus & $2.2 \pm 0.10$ \\
\hline Penicillium digetatum & $2.5 \pm 0.00$ \\
\hline Aspergillus sediwii (isolate No. 2) & $2.4 \pm 0.11$ \\
\hline Aspergillus niger (isolate No. 2) & $4.2 \pm 0.10$ \\
\hline Aspergillus flavus (isolate No. 3) & $4.2 \pm 0.05$ \\
\hline Aspergillus candidus (isolate No. 2) & $2.3 \pm 0.10$ \\
\hline Aspergillus terrus & $2.8 \pm 0.15$ \\
\hline Aspergillus niger (isolate No. 3) & $6.8 \pm 0.20$ \\
\hline Aspergillus flavus (isolate No. 4) & $5.2 \pm 0.25$ \\
\hline Aspergillus ochraceus & $2.9 \pm 0.17$ \\
\hline Penicillium notatum & $2.8 \pm 0.11$ \\
\hline Aspergillus fumigates & $6.2 \pm 0.10$ \\
\hline Mucor sp (isolate No. 1) & $2.6 \pm 0.10$ \\
\hline Mucor sp (isolate No. 2) & $2.2 \pm 0.10$ \\
\hline Circinella simplex & $0.0 \pm 0.00$ \\
\hline Alternaria alternate & $3.4 \pm 0.10$ \\
\hline Rhodotorula spp. & $3.2 \pm 0.10$ \\
\hline F-value & $1213.02 * * *$ \\
\hline
\end{tabular}

All data represented means of 3 replica \pm standard Deviation (SD). The P-value is $<0.001$. Results nonsignificant $=$ non-significant difference at $\mathrm{P}>0.05$, *significant at $\mathrm{P} \leq 0.05$, **highly significant at $\mathrm{P} \leq$ $0.01, * * *$ very highly significant at $\mathrm{P} \leq 0.001$. 


\subsubsection{Screening for cellulase activity} using liquid culture

Data represented in Table $\mathbf{3}$ indicated that the maximum carboxymethyl cellulase (CMCase) activity was recorded by Aspergillus niger isolate $1(28.9 \mathrm{U} / \mathrm{ml})$ followed by Trichoderma viride and Aspergillus fumigates with (26.1 and $24.7 \mathrm{U} / \mathrm{ml})$ respectively, activities of other remaining isolates were ranged between (24 to $6.9 \mathrm{U} / \mathrm{ml}$ ). Also, the maximum $\beta$ glucosidase ( $\beta$ Gase) activity was recorded by Aspergillus niger isolate 1 (43.9 U/ml) and the other remaining isolates ranged between (26.0 to 8.1 $\mathrm{U} / \mathrm{ml}$ ). Filter-paper cellulase (FPase) activity was the highest when Aspergillus fumigates was applied and recorded $(10.2 \mathrm{U} / \mathrm{ml})$ and the other remaining isolates ranged between (10.0 to $2.9 \mathrm{U} / \mathrm{ml}$ ).

Also, Table 3 indicated that the total cellulolytic activity was recorded by Aspergillus niger isolate $1(79.3 \mathrm{U} / \mathrm{ml})$, and the remaining isolates were ranged from $(61.6$ to $19.5 \mathrm{U} / \mathrm{ml})$ 
Table 3. Screening for the cellulolytic activity of tested fungi in liquid culture

\begin{tabular}{|c|c|c|c|c|}
\hline \multirow{2}{*}{ Fungal species } & \multicolumn{4}{|c|}{ Enzymatic activity (U/ml) } \\
\hline & CMCase & BGase & Fpase & Total activity \\
\hline Trichoderma vir & $26.1 \pm 0.3$ & $25.4 \pm 0.6$ & $8.0 \pm 0.4$ & $59.5 \pm 1.3$ \\
\hline Cladosporium Cladosporides & $7.8 \pm 0.6$ & $8.7 \pm 0.4$ & $3.4 \pm 0.1$ & $19.9 \pm 1.1$ \\
\hline Aspergillus sediwii (isolate 1) & $16.0 \pm 0.5$ & $18.6 \pm 0.3$ & $8.2 \pm 0.3$ & $42.8 \pm 1.1$ \\
\hline Botritricum spp. & $20.5 \pm 0.4$ & $18.9 \pm 0.3$ & $6.9 \pm 0.4$ & $46.3 \pm 1.1$ \\
\hline Aspergillus niger (isolate 1) & $28.9 \pm 0.3$ & $43.9 \pm 0.3$ & $6.5 \pm 0.4$ & $79.3 \pm 1.0$ \\
\hline $\begin{array}{l}\text { Cephalosporium } \\
\text { grisium saksena }\end{array}$ & $8.6 \pm 0.5$ & $8.1 \pm 0.2$ & $4.5 \pm 0.4$ & $21.2 \pm 1.1$ \\
\hline Fusarium oxysporium & $18.0 \pm 0.7$ & $23.1 \pm 0.6$ & $4.5 \pm 0.3$ & $45.6 \pm 1.6$ \\
\hline Aspergillus flavus (isolate 1) & $21.0 \pm 0.3$ & $19.9 \pm 0.2$ & $4.8 \pm 0.1$ & $45.7 \pm 0.6$ \\
\hline Aspergillus candidus (isolate 1) & $10.2 \pm 0.3$ & $12.0 \pm 0.2$ & $7.8 \pm 0.3$ & $30.0 \pm 0.8$ \\
\hline Aspergillus flavus (isolate 2) & $20.5 \pm 0.6$ & $23.3 \pm 0.6$ & $8.4 \pm 0.1$ & $52.2 \pm 1.3$ \\
\hline Aspergillus fumigates & $24.7 \pm 0.6$ & $23.5 \pm 0.1$ & $10.2 \pm 0.1$ & $58.4 \pm 0.8$ \\
\hline Cephalosporium spp. & $16.1 \pm 0.5$ & $14.9 \pm 0.1$ & $5.4 \pm 0.6$ & $36.4 \pm 1.2$ \\
\hline Aspergillus sulphorus & $14.0 \pm 0.4$ & $16.6 \pm 0.2$ & $7.6 \pm 0.1$ & $38.2 \pm 0.7$ \\
\hline Penicillium digetatum & $17.2 \pm 0.4$ & $20.5 \pm 0.3$ & $5.9 \pm 0.4$ & $43.6 \pm 1.1$ \\
\hline Aspergillus sediwii (isolate 2) & $18.8 \pm 0.6$ & $19.8 \pm 0.4$ & $5.3 \pm 0.4$ & $43.9 \pm 1.4$ \\
\hline Aspergillus niger (isolate 2) & $20.3 \pm 0.5$ & $26.0 \pm 0.3$ & $8.9 \pm 0.2$ & $55.2 \pm 1.0$ \\
\hline Aspergillus flavus (isolate 3) & $17.0 \pm 0.4$ & $18.0 \pm 0.3$ & $4.8 \pm 0.2$ & $39.8 \pm 0.9$ \\
\hline Aspergillus candidus (isolate 2) & $13.9 \pm 0.1$ & $13.9 \pm 0.1$ & $5.8 \pm 0.1$ & $33.6 \pm 0.3$ \\
\hline Aspergillus terrus & $19.6 \pm 0.4$ & $17.8 \pm 0.9$ & $5.4 \pm 0.1$ & $42.8 \pm 1.4$ \\
\hline Aspergillus niger (isolate 3) & $24.0 \pm 0.6$ & $27.6 \pm 0.7$ & $10.0 \pm 0.1$ & $61.6 \pm 1.4$ \\
\hline Aspergillus flavus (isolate 4) & $20.9 \pm 0.4$ & $23.6 \pm 0.6$ & $5.8 \pm 0.1$ & $50.3 \pm 1.1$ \\
\hline Aspergillus ochracous & $15.7 \pm 0.5$ & $10.5 \pm 0.6$ & $6.2 \pm 0.1$ & $32.4 \pm 1.2$ \\
\hline Penicillum notatum & $15.2 \pm 0.5$ & $14.2 \pm 0.4$ & $3.7 \pm 0.2$ & $33.1 \pm 1.1$ \\
\hline Mucor spp. (isolate 1) & $6.9 \pm 0.6$ & $9.7 \pm 0.1$ & $2.9 \pm 0.1$ & $19.5 \pm 0.8$ \\
\hline Mucor spp. (isolate 2) & $6.9 \pm 0.4$ & $9.7 \pm 0.6$ & $2.9 \pm 0.1$ & $19.5 \pm 1.1$ \\
\hline Alternaria alternate & $11.7 \pm 0.9$ & $13.6 \pm 0.3$ & $7.0 \pm 0.1$ & $32.3 \pm 1.3$ \\
\hline Rhodotorula spp. & $16.3 \pm 0.1$ & $15.8 \pm 0.1$ & $7.6 \pm 0.1$ & $39.7 \pm 0.3$ \\
\hline F-value & $17.65 * * *$ & $53.42 * * *$ & $53.42 * * *$ & $186.42 * * *$ \\
\hline
\end{tabular}

All data represented means of 3 replica \pm standard Deviation $(\mathrm{SD})$. The P-value is $<0.001$. Results nonsignificant $=$ non-significant difference at $\mathrm{P}>0.05$, *significant at $\mathrm{P} \leq 0.05$, **highly significant at $\mathrm{P} \leq 0.01$, $* * *$ very highly significant at $\mathrm{P} \leq 0.001$. 


\section{Discussion}

Annually, about 180 billion tons of cellulose were produced by plants, and it's a principal source of organic carbon in the world. Cellulose is the most abundant polymer and renewable resource that available worldwide (Thottiam et al., 2018), and it accounts for a major portion of agricultural waste deposited in the soil, therefore its decomposition is crucial to the carbon cycle (Pandey et al., 2020). The Fungi are the best decomposition agents for organic matter generally and cellulosic substrate particularly. These fungi can secrete a variety of extracellular enzymes to decompose the lignocellulosic substrate. Among the variety of enzymes, cellulase is one of the most important for the decomposition of lignocellulosic materials (El-Sheekh et al., 2009; Gahfif et al., 2020; Pandey et al., 2020).

In this study, isolated fungal species from different sources were identified and screened for cellulase activities. Thirty-one species were identified based on their macro-morphological features, such as colony diameter, colony reverse, texture, colony colour, margin, and exudates. Slide culture technique was used to characterize fungal isolates based on micromorphological parameters such as hyphal structure, conidiophore structure organization, size and form of conidia, conidia arrangement, phialides, and so on (Londhe et al., 2019).

Screening for cellulase activity based on clear zones was done on CMC agar plates that had been flooded with Congo red $(0.1 \% \mathrm{w} / \mathrm{v})$, then de-stained with $1 \mathrm{M} \mathrm{NaCl}$ and 5\% acetic acid. 27 fungal species were identified as Cellulase-producing fungi according to the diameter of the clear zone around the colony. Aspergillus niger isolate 1 and Trichoderma viride gave the highest clear zone. Generally, cellulases production has been reported in a wide variety of fungi (Sarao et al., 2010), especially filamentous fungi, which can produce high amounts of these enzymes compared to another microbial community (Mrudula and Murugammal, 2011). Similar results were obtained by Zhang $\boldsymbol{e t}$ al.., (2018) who reported that members of the genera Aspergillus and Trichoderma were the most common fungi with cellulolytic activity. Also, Darwesh et al. (2020) showed that Aspergillus niger gave the highest clear zone that showed the largest halo forming zone when all plates were flooding with Congo red.

Results obtained from the screening of cellulolytic tested fungi using liquid medium revealed that the highest total cellulolytic activity was recorded by Aspergillus niger isolate 1 . The same results were obtained by Darwesh et al., 
(2020). Also, results showed that isolate No. 1 of Aspergillus niger from AlGharbia is more cellulolytic than isolates No $2 \& 3$ of Aspergillus niger isolated from Aswan. Moreover, the cellulolytic activity of isolate No.1 of Aspergillus sediwii from Al-Gharbia and isolate No. 2 of Aspergillus sediwii from Aswan were approximately equal but Aswan isolate was a little high on Al-Gharbia isolate. Among four Aspergillus flavus isolates (isolate No. $1 \& 2$ from Al-Gharbia) and (isolate $3 \& 4$ from Aswan), Aspergillus flavus isolate 2 was more cellulolytic than other A. flavus isolates. On the other hand, Aspergillus candidus isolate 2 from Aswan recorded cellulolytic activity higher than $A$. candidus isolate 1 that isolated from AlGharbia.

Quintanilla et al., (2015); Liu and Kokare, (2017); Buntić et al., (2019)reported that fungal cellulases have a different specificity and action mode rather than bacterial cellulases.

\section{Conclusion}

This study revealed that Aspergillus niger and Trichoderma viride are promising fungi that have cellulolytic activity. Therefore, we recommend the use of these promising isolates in further study to improve the production of cellulase enzyme for use in saccharification and the use of the resulting reducing sugars in the production of bioethanol.

\section{References}

Booth, C. (1971). The genus Fusarium. Commonwealth Mycological Institute Kew, Surrey, UK.

Buntić, A. V.; Milić, M. D.; StajkovićSrbinović, O. S.; Rasulić, N. V.; Delić, D. I. and Mihajlovski, K. R. (2019). Cellulase production by Sinorhizobium meliloti strain 224 using waste tobacco as substrate. International Journal of Environmental Science and Technology, 16(10): 5881-5890.

Celestino, J. D. R.; Carvalho, L. E. De.; Lima, M. D. P.; Lima, A. M.; Ogusku, M. M.; and Souza, J. V. B. De. (2014). Bioprospecting of Amazon soil fungi with the potential for pigment production. Process Biochemistry, 49(4): 569-575.

Cruz-Lachica, I.; Marquez-Zequera, I.; Allende-Molar, R.; Sañudo-Barajas, J. A.; Leon-Felix, J.; Ley-Lopez, N. and Garcia-Estrada, R. S. (2018). Diversity of mucoralean fungi in soils of papaya (Carica papaya L.) producing regions in Mexico. Fungal Biology, 122(8): 810-816.

Darwesh, O. M.; El-Maraghy, S. H.; Abdel-Rahman, H. M. and Zaghloul, R. A. (2020). Improvement of paper wastes conversion to bioethanol using novel cellulose degrading fungal isolate. Fuel, 262: 116518.

Domsch, K.H.; Gams, W. and Anderson, T. H. (1980). Compendium of soil fungi. Academic Press (London) Ltd., 1: 703-709. 
Duarte, A. W. F., Santos, J. A. dos, Vianna, M. V., Vieira, J. M. F., Mallagutti, V. H., Inforsato, F. J. and Sette, L. D. (2017). Cold-adapted enzymes produced by fungi from terrestrial and marine Antarctic environments, 38(4): 600-619.

Duncan, D. B. (1955). Multiple range and multiple F tests. Biometrics. 11(1): 142.

Ejaz, U.; Sohail, M. and Ghanemi, A. (2021). Cellulases: From Bioactivity to a Variety of Industrial Applications. Biomimetics, 6(3): 44.

El-Sheekh, M.M., Ismail, A.S., El-Abd, M.A., Hegazy, E.M., and El-Diwany, A.I. (2009). Effective Technological Pectinases by Aspergillus carneus NRC1 Utilizing the Egyptian OrangeJuice Industry Scraps. International Biodeterioation \& Biodegradation. 63: 12-18.

Gahfif, o.; Souagui, y.; Azzouz, z.; Nouari, s.; Amghar, z. a. z.; Boucherba, n. and Bettache, a. (2020). Isolation and Screening of Fungal Culture Isolated From Algerian Soil for the Production of Cellulase and Xylanase. Journal of Drug Delivery and Therapeutics, 10(5-s): 108-113.

Hasanin, M. S.; Mostafa, A. M.; Mwafy, E. A. and Darwesh, O. M. (2018). Ecofriendly cellulose nano fibers via first reported Egyptian Humicola fuscoatra Egyptia X4: Isolation and characterization. Environmental Nanotechnology, Monitoring \& Management, 10: 409-418.
Jasani, H.; Umretiya, N.; Dharajiya, D.; Kapuria, M.; Shah, S. and Patel, J. (2016). Isolation, Optimization and Production of Cellulase by Aspergillus niger from Agricultural Waste Removal of textile dyes from wastewater using fungi View project Antimicrobial activity of medicinal plants View project. J. pure Appl. Microbiol, 10 (2): 159-1167.

Kitch, M. A. and Pitt J. I. (1992). laboratory guide to the commen Aspergillus species and their teleomorphs. CSIRO, Sydney. Common Wealth Scientific and Industrial Research Organisation, Division of Food Processing.

Klysov, A. A. (1990). Trends in Biochemistry and Enzymology. Biochemistry, 29, 10577-10585.

Liu, X. and Kokare, C. (2017). Microbial Enzymes of Use in Industry. Biotechnology of Microbial Enzymes: Production, Biocatalysis and Industrial Applications, 267-298.

Londhe, S.; Patil, S.; Krishnadas, K.; Sawant, A. M.; Yelchuri, R. K. and Chada, V. G. R. (2019). Fungal diversity on decorative paints of India. Progress in Organic Coatings, 135: 1-6.

Mandels, M.; Andreotti, R. and Roche, C. (1976). Measurement of saccharifying cellulase. Biotechnol. Bioeng. Symp.;(United States)., 6: 21-23.

Moubasher, A. H. and Abdel-Hafez, S. I. (1978). Study on the mycoflora of Egyptian soils. Mycopathologia, 6(1): 3-10. 
Mrudula, S. and Murugammal, R. (2011). Production of cellulase by Aspergillus niger under submerged and solid state fermentation using coir waste as a substrate. Brazilian Journal of Microbiology, 42(3): 1119-1127.

Nathan, V. K., Esther Rani, M., Rathinasamy, G., Dhiraviam, K. N. and Jayavel, S. (2014). Process optimization and production kinetics for cellulase production by Trichoderma viride VKF3. SpringerPlus, 3(1): 1-12.

Pandey, S.; Sharma, T.K. and Dassani, S. (2020). isolation and screening of cellulolytic fungi from degrading leaf litter of saccharum officinarum 1 . Plant Archives, 20(2): 7013-7020.

Quintanilla, D.; Hagemann, T.; Hansen, K. and Gernaey, K. V. (2015). Fungal Morphology in Industrial Enzyme Production-Modelling and Monitoring. Advances in Biochemical Engineering/Biotechnology, 149: 2954.

Raper, K.B. and Fennell, D. I. (1977). The genus Aspergillus Robert EK. Publish, co., Huntington, New York, 686.

Rathore, S.S.; Mannivannan, A. and Narendhirakannan, R.T. (2014). Screening of cellulase producing microorganisms from lake area containing water hyacinth for enzymatic hydrolysis of cellulose. Journal of Advanced Scientific Research, 5(3): 23-30.

Reddy, P.L.N.; Bahu B.S.; Radhaiah. A. and Sreeramulu. A. (2014). Screening Identification and isolation of cellulolytic fungi from soil of Chittoor District, India. International Journal of Current Microbiology and Applied Science, 3(7): 761-771.

Sarao, L. K.; Arora, M. and Sehgal, V. K. (2010). Use of Scopulariopsis acremonium for the production of cellulase and xylanase through submerged fermentation. African Journal of Microbiology Research, 4(14): 1506-1509.

Sari, s.l.a.; Pangastuti, a.; Susilowati, a.; Purwoko, t.; Mahajoeno, e.; Hidayat, w.; Mardhena, i., Kurniawati, d. and Anitasari, r. (2016). No TitleCellulolytic and hemicellulolytic bacteria from the gut of Oryctes rhinoceros larvae. Biodiversitas Journal of Biological Diversity. 17(1).

Sari, s. 1. a.; Setyaningsih, r. and Wibowo, n. f. a. (2017). Isolation and screening of cellulolytic fungi from Salacca zalacca leaf litter. Biodiversitas Journal of Biological Diversity, 18(3): 1282-1288.

Thottiam Vasudevan, R.; Sundarraj, A. A. and Ranganathan, V. (2018). A review on cellulose and its utilization from agro-industrial waste Recent trends in Nnaotechnology in Food Processing and its various applications. Drug Invention Today, 10(1): 89-94.

Zhang, F.; Zhao, X. and Bai, F. (2018). Improvement of cellulase production in Trichoderma reesei Rut-C30 by overexpression of a novel regulatory gene Trvib-1. Bioresource Technology, 247: 676-683. 


\section{عزل و تعريف و فحص الفطريات المحلله للسيليوز من مصادر وأماكن مختلفه فى مصر}

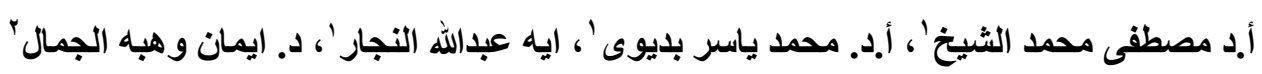

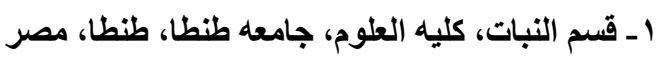

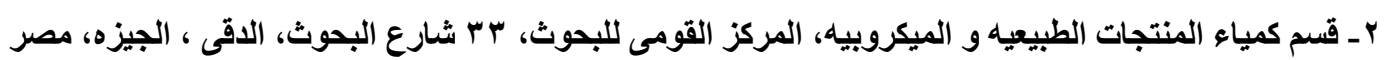

انزيم السليولاز عباره عن سلسله من الانزيمات التى تحلل السليلوز الى سكر بسيط. فى هذه الدراسه تم

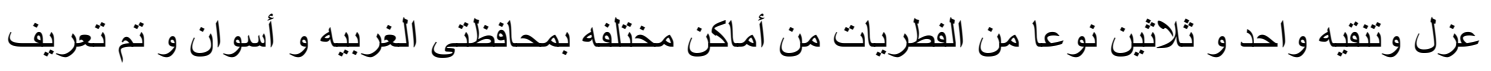
هذه الفطريات وكانت تنتمى الى أثنى عشر جنسا وهى تُ ترايكوديرما، كلادوسبوريم، اسبرجيللس، بوتريتريكم، ريزوبس، سيفالوسبوريم، فيوزاريم، بنسليوم، ميوكر، سيرسينيلا، الترنارياو الخميره. و تم تم

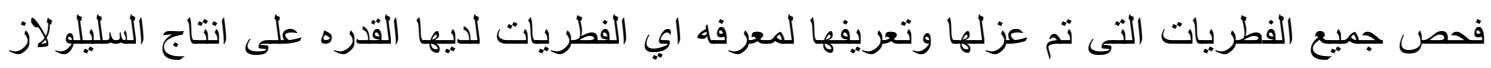

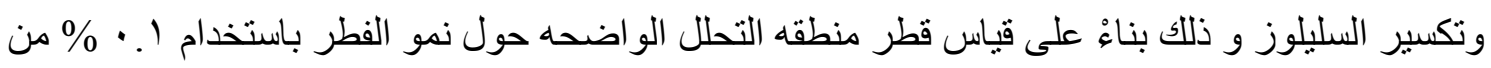

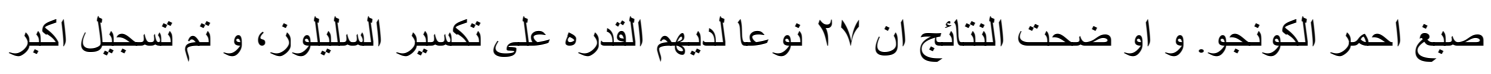

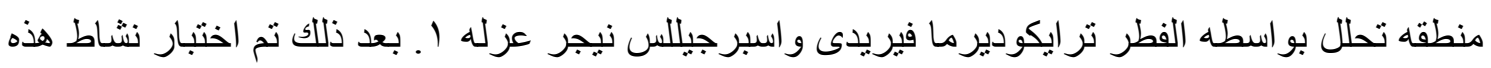

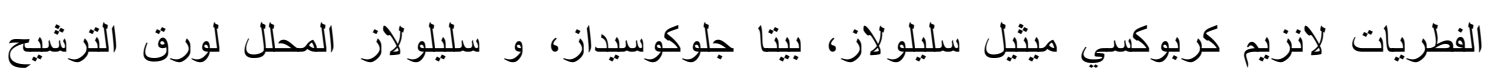

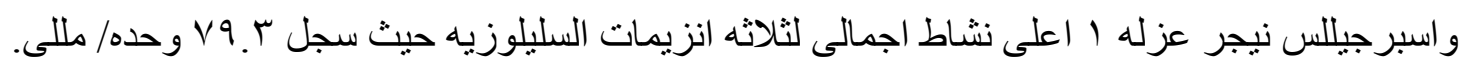

